\title{
Kontribusi al-Qur'an terhadap Perkembangan Bahasa Arab
}

\author{
Nurul Hadi \\ Dosen STAIN (Sekolah tinggi Agama Islam Negeri) Pamekasan \\ Email: nurulhadi@gmail.com
}

Absrak:

Tulisan ini akan menyajikan sejauh mana kontribusi al-Qur'an alKarim terhadap perkembangan Bahasa Arab. Perkembangan itu dapat kita lihat secara lebih konret ketika membandingkan fenomena Bahasa Arab sebelum al-Qur'an turun dan sesudahnya. Lebih jauh lagi, kontribusi itu akan terlihat sangat nyata ketika eksistensi Bahasa Arab dikomparasikan dengan keberadaan bahasa lain. Adapun beberapa poin kontribusi al-Qur'an terhadap Bahasa Arab antara lain (1) menjaga eksistensi Bahasa Arab; (2) menambah kosa kata Bahasa Arab; (3) menambah cakupan makna Bahasa Arab; (4)menambah gaya bahasa (uslūb) Bahasa Arab; (5)menyatukan lahjah Bahasa Arab; (6) memperluas ketersebaran Bahasa Arab; (7) memperkaya sastra Bahasa Arab; (8) menjadi sumber munculnya ilmu-ilmu Bahasa Arab.

Kata kunci: Al-Qur'an; Bahasa Arab; Kontribusi; Gaya Bahasa; Makna.

Abstract:

$$
\begin{aligned}
& \text { هذذا المقال المتواضع سنعرف مدى تأثير القرآن الكريم في اللغة العربية وتطورها عبر تاريخها الطويل }
\end{aligned}
$$

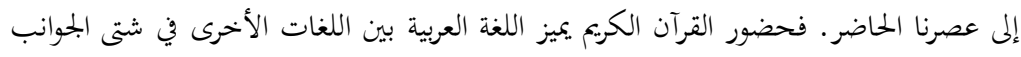

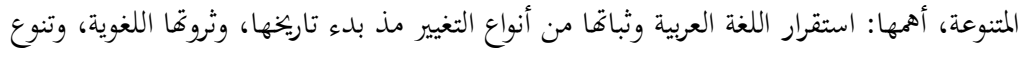

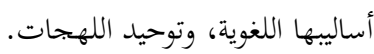

Keywords : استقرار اللغة ; أساليب اللغة;اللهجات ; اللغة العربية ; تأثير القران

\section{Prolog}

Bahasa Arab seperti bahasa pada umumnya; muncul lalu hidup dan terus berkembang. Bahkan ada juga bahasa yang kemudian mengalami kematian ${ }^{1}$. Sementara itu Bahasa Arab juga mengalami proses kemunculan,

\footnotetext{
1 Bahasa mati adalah bahasa yang tidak memiliki penutur asli lagi atau memang tidak dipergunakan lagi. Sebuah bahasa apabila tidak didokumentasikan akan hilang selamanya apabila sudah tidak ada penuturnya lagi. Tetapi apabila didokumentasikan maka bahasa tersebut akan "dihidupkan" lagi. Di antara bahasa mati terrsebut adalah: (1) Bahasa Sumeria yang pernah dituturkan di daerah yang sekarang disebut Irak. (2) Bahasa Galia yang
} 
lalu hidup dan berkembang ${ }^{2}$, tetapi bahasa ini memiliki keistimewaan tersendiri karena tidak akan mati selama-lamanya ${ }^{3}$.

Kemunculan bahasa Arab memang masih menjadi perdebatan, sebab sangat sulit untuk membuktikan sejak kapan suatu bahasa itu muncul? Karena tidak adanya bukti-bukti konkret berupa artefak atau lainnya yang dapat memastikan kemunculan bahasa Arab secara meyakinkan ${ }^{4}$. Beberapa penelitian menggunakan pendekatan historis dan konsep "keterpengaruhan" untuk menentukan bahasa apa yang lebih awal dan paling banyak mempengaruhi bahasa lainnya.

Apakah bahasa Arab turunan dari Bahasa Semit ${ }^{5}$ atau justru Bahasa Arab yang menjadi induknya? Secara umum, ahli bahasa mengelompokkan bahasa Arab ke dalam bahasa Semit. Karena banyaknya kesamaan dan kemiripan dalam anasir bahasanya ${ }^{6}$. Tetapi ada juga yang berpendapat bahwa sesungguhnya Bahasa Arab-lah yang menjadi induk, bahkan asalmuasal dari semua bahasa di dunia, sedangkan bahasa-bahasa lain merupakan lahjāh (dialek-dialek) yang berasal darinya ${ }^{7}$.

Banyak sejarahwan sepakat bahwa dokumentasi teks Bahasa Arab yang pertama kali ditemukan adalah sekitar abad ketiga sampai abad kelima setelah masehi; yaitu al-shi'r al-Jähili ${ }^{-8}$. Teks-teks yang berupa puisi sastra Arab klasik ini telah mengalami kematangan dan kesempurnaan bahasa Arab. Sementara perkembangan bahasa itu sangatlah lambat, karena bahasa itu hidup hanya dalam komunitas penuturnya dan baru berkembang ketika

dituturkan di daerah yang sekarang disebut Prancis. (diambil dari http://id. wikipedia. org/wiki/Bahasa mati diakses tangggal 18-05-2015).

${ }^{2}$ Joergi Zidane melakukan penelitian tentang proses yang dialami bahasa Arab ini, mulai dari kemunculannya dan perkembangan bahasa ini sampai kepada kita sekarang. Hasil penelitiannya diterbitkan dalam sebuah buku yang diberi judul "اللغة العربية كائن حي (artinya: Bahasa Arab adalah bahasa yang hidup). Lihat selengkapnya di: Joergi Zidane, al-Lughah al'Arabiyah Käinun Hayyun (Beirut: Dār al-Jaìl, cet. Ke-8, 1988).

${ }^{3}$ Jaminan keberlangsungan Bahasa Arab setidaknya tercantum dalam al-Qu'an (QS. al-Hijr [15]: 9.

4 Abdul Karim al-Bughbisisi, "Daūr al-Qur'ān fi Tatawwur al-Lughah al-'Arabiyah wa $\bar{A} d \bar{b} b i h \bar{a}$ ” dalam http://www. diwanalarab.com/spip.php? page $=$ article\&id_article $=25795$ diakses tanggal 18 Mei 2015.

${ }^{5}$ Bahasa Semit adalah rumpun dari beberapa bahasa antara lain: Bahasa Babel, Bahasa Ibrani, Bahasa Suryani, Bahasa Phoenician, Bahasa Aram, Bahasa Abyssinian (Habsyah) dan Bahasa Arab. Tetapi, Bahasa Arab merupakan bahasa yang paling dekat keserupaannya dengan bahasa Semit. (Zainal 'Abiđin Haji Abdul Qādir, Mudzakkirah fí Tārīkh al-Adab al-Arabī, (Kuala Lumpur: Kementerian Pendidikan Malaysia, 1987), 13.

${ }^{6}$ Abdu al-Rahmān Ahmad al-Būrinīi, al-Lughah al-'Arabiyah 'Aṣlu al-Lughāt Kullihāā, (Oman: Dār al-Hasan, 1998), 48.

${ }^{7}$ Ibid. 12

${ }^{8}$ Shauqui Ḍif, Tārikh al-Adab al-'Arabī al-'Aṣr al-Jāhili, (Kairo: Dār al-Ma'ārif, 2003), 38. 
penutur bahasa tersebut mampu berinteraksi lebih luas dengan penutur bahasa lainnya ${ }^{9}$. Dengan demikian, dapat dipastikan bahwa kemunculan Bahasa Arab telah dimulai jauh sebelum puisi-puisi Arab jāhili ini ditemukan.

Lalu perkembangan Bahasa Arab mulai menemukan lahan suburnya pada saat Islam datang. Hal itu dapat terlihat dengan sangat jelas dalam buku Joerji Zidane, al-Lughah al-'Arabiyah Käinun Hayyun. Buku ini mendeskripsikan secara detail perkembangan Bahasa Arab dalam beberapa fase, di antaranya ${ }^{10}$ :

1. Masa Jāhiliyah: pada masa ini Bahasa Arab mendapatkan beberapa perkembangan dari segi kata-kata dan struktur sebelum Islam.

2. Masa Islam: pengaruh Islam sangat tanpak dalam kata-kata Bahasa Arab dan gaya bahasanya.

3. Kemunculan istilah-istilah administrasi pada masa-masa pemerintahan Islam (dari al-Khilāfah al-Rāsyidah dan al-Daulah al-Islāmiyah al-’Arabiyah lainnya).

4. Kemunculan istilah-istilah ilmiah.

5. Kemunculan istilah-istilah sosial.

6. Kemunculan istilah-istilah nașrāniyah.

7. Kemunculan istilah-istilah non-Arab.

8. Masa kebangkitan modern.

Keberadaan fase-fase di atas didasarkan pada adanya perkembangan terhadap Bahasa Arab yang terjadi karena adanya penambahan kosakata baru atau adanya gaya bahasa (uslüb al-lughah) baru. Kendati demikian, perkembangan bahasa Arab tersebut bukan berarti mengganti kosakata atau struktur yang sudah ada sebelumnya. Jadi, perkembangan yang terjadi lebih bersifat memperkaya bahasa Arab bukan malah merekonstruksi yang ada.

Oleh karena itu, kemunculan bahasa Arab dan perkem-bangannya sampai sekarang bahkan eksistensinya di masa-masa yang akan datang berbeda dengan bahasa-bahasa lainnya. Di mana perkembangan bahasa lain bersifat rekonstruktif atau paling tidak terjadi revisi pada bahasa sebelumnya; baik berupa ejaan, bacaan ataupun makna, tetapi hal itu tidak terjadi dalam bahasa Arab. Sedangkan perkembangan dalam Bahasa Arab bersifat penambahan atau penggunaan kata dengan makna yang berbeda tanpa menghapus makna sebelumnya.

\footnotetext{
${ }^{9}$ Joerji Zidane, al-Lughah al-’'Arabiyah Kāinun Hayyun, (Beirut: Dār al-Jaìl, cet. Ke-8, 1988), 9 .

${ }^{10}$ Ibid, 11
} 
Yang menarik perhatian, kenapa Bahasa Arab berbeda dengan bahasa lain? Kenapa keistimewaan ini ada pada bahasa Arab? Faktor apa sesungguhnya yang melatarbelakangi perkembangan Bahasa Arab dengan semua keistimewaannya itu?

Dari beberapa permasalahan di atas, tulisan sederhana ini akan menjelaskan bahwa keistimewaan Bahasa Arab tersebut tidak terjadi secara kebetulan. Dan apa yang terjadi dalam Bahasa Arab bukan karena faktor bahasa Arab itu sendiri secara internal, tidak pula karena faktor orang Arab sebagai penutur. Kalau demikian, pasti ada faktor ekternal yang sangat berpengaruh terhadap Bahasa Arab. Faktor eksternal itu adalah al-Qur'an alkārim. Mengapa? Mari kita awali pembahasan ini dengan terlebih dahulu mengetahui kehadiran al-Qur'an dan kondisi Bahasa Arab pada saat itu.

\section{Kehadiran al-Qur'an al-Karim}

Al-Qur'an adalah kitab suci agama Islam. Kitab ini merupakan firman Allah (kalām Allah) yang menjadi mu'jizat, diturunkan kepada Nabi Muhammad Saw. melalui Malaikat Jibril as. yang ditulis dalam mushhaf dengan riwayat yang mutawatir, orang yang membacanya mendapat pahala, kitab ini dimulai dengan surah al-Fātihah dan diakhiri dengan surah al-Nās. ${ }^{11}$

Al-Qur'an hadir di mana Bahasa Arab dalam puncak kematangan. Tentu saja, kitab suci ini ada bersamaan dengan datangnya Islam sebagai agama, yang menandakan berakhirnya masa Jāhiliyah. Pada saat itu, orangorang Arab sudah lama memiliki tradisi membuat syi'ir (cipta puisi) secara langsung non-literal. Pembacaan puisi disajikan dengan model kompetisi antar sastrawan dari pelbagai kabilah. Masing-masing sastrawan tersebut membanggakan kabilahnya dengan fanatisme tinggi. Namun demikian penggunaan Bahasa Arab mengalahkan fanatisme terhadap kabilahnya dalam hal pembuatan syi'ir. Meskipun kabilah mereka mempunyai dialek (lahjah) sendiri, tetapi Bahasa Arab yang sesungguhnya didominasi oleh lahjah Quraish ini menjadi pilihan bersama sebagai bahasa persatuan (allughah al-mushtarakah $\left.{ }^{12}\right)^{13}$

Kompetisi cipta puisi dalam bentuk qașidah ini dilaksanakan di pasarpasar Arab setiap tahun sekali. Pasar-pasar yang biasa dijadikan tempat

\footnotetext{
11 Khaldūn Ibrāhim Salāmah, al-Thaqāfah al-Islāmiyah al-Mustawā al-Thālith, (Riyadh: Jāmi' ah al-Imām Muhammad bin Saud al-Islāmiyah, tt), 15

12 Dinamakan bahasa persatuan (al-lughah al-mushtarakah) karena bahasa ini terdiri dari perbagai kabilah Arab terutama dari al-Qahțāniyah dan al-'Adnāniyah. Orang Arab mengambil lahjah terbaik dan paling fasih dari masing-masing kabilah. Tetapi secara umum bahasa persat uan Arab itu didominasi oleh lahjah Quraish. (Zainal Abidin: 1987), 18)

${ }^{13}$ Shauqi Dîif, Op.Cit., 131
} 
untuk unjuk keindahan sastra Arab ini ada tiga tempat yang semuanya berada di Hijaz. Pasar-pasar itu adalah: 'Ukaz, Dzū al-Majāz, dan Mujanah $^{14}$. Seiring bertambahnya tahun kompetisi tersebut semakin mapan. Konon kompetisi tersebut dikemas semacam kontes dengan menghadirkan dewan juri yang kompeten sekaligus menjadi komentator terhadap karya sastra yang ditampilkan dalam ajang tahunan tersebut. Karya sastra terbaik diapresiasi dengan menuliskan hasil karya sastranya di atas kain dengan tinta emas kemudian digantung di dinding Ka'bah. Karya-karya sastra terbaik masa Jahiliyah itu ada tujuh buah yang digantungkan di Ka'bah, sehingga ketujuh buah karya itu terkenal dengan nama al-mu'allaqāt al$s a b^{\prime} a h^{15}$ (tujuh yang digantung). ${ }^{16}$

Dari gambaran di atas, kita dapat simpulkan bahwa pada saat Islam datang kondisi Bahasa Arab berada pada puncak kematangan. Sedangkan penduduk bangsa Arab sedang maniak sastra. Maka kehadiran al-Qur'an dengan Bahasa Arab al-musytarakah tadi serta ditopang dengan penggunaan gaya bahasa (uslüb) yang unik menjadi kejutan dan pusat perhatian yang sangat surprise. Bahkan, al-Qur'an berhasil mengalihkan fokus perhatian orang Arab dengan gaya bahasanya sendiri yang khas. Konon juga tidak sedikit orang-orang Arab yang menjadi luluh hatinya saat mendengar lantunan ayat-ayat al-Qur'an. Di antara mereka yang tersentuh hatinya adalah Umar bin al-Khațāa dan al-Wālid bin al-Mughïrah yang akhirnya memeluk Islam gara-gara mendengarkan lantunan ayat-ayat suci al-Qur' an ${ }^{17}$.

Kehadiran al-Qur'an al-Karim sebagai pedoman hidup tentu saja banyak memberikan kontribusi dalam pelbagai bidang kehidupan; baik dalam bidang pendidikan, sosial, politik, ekonomi, ilmu pengetahuan (sains) dan terutama bidang agama. Di samping itu semua, secara spesifik, alQur'an juga mempunyai kontribusi yang sangat besar terhadap Bahasa Arab dan perkembangannya. Kontribusi itu terjadi dalam beberapa aspek, berikut ini penulis akan menjelaskan aspek-aspek tersebut secara lebih mendetail:

\section{Kontribusi al-Qur'an Terhadap Bahasa Arab}

Secara garis besar ada beberapa pengaruh al-Quran terhadap perkembangan Bahasa Arab. Pengaruh adanya al-Qur'an ini sangat besar dan

\footnotetext{
${ }^{14}$ Ibid, 17

${ }^{15}$ Para Sastrawan masa Jahiliyah yang karyanya termasuk ke dalam al-Mu'allaqāt al-Sab'ah adalah 1. Umra'ul Qais; 2. Tharafah bin al-'Abd; 3. Zuhaīr bin Abī Sulmā; 4. Al-Lubaid bin Rabi' ah; 5. Amr bin Kulthūm; 6. 'Antarah bin Syadād al-Abshī; 7. Al-Hārith bin Hillizah alYashkari.

${ }^{16}$ Ibid. 30 .

${ }^{17}$ Sayyid Ibrāhīm Muhammad al-Dad, Muhadharāt fì Târìkh al-Adab al-'Arabī ' Ashr Sadri al-Islām, (Kairo: Jāmi'at al-Azhar, 2004), 15
} 
konkret sehingga layak untuk disebut sebagai kontribusi. Berikut kontribusi al-Qur'an tersebut:

1. Menjaga eksistensi Bahasa Arab;

2. Menambah kosa kata Bahasa Arab;

3. Menambah cakupan makna Bahasa Arab;

4. Menambah gaya bahasa (uslüb) Bahasa Arab;

5. Menyatukan lahjah Bahasa Arab;

6. Memperluas ketersebaran Bahasa Arab;

7. Memperkaya sastra Bahasa Arab;

8. Menjadi sumber munculnya Ilmu-ilmu Bahasa Arab.

Sedangkan rincian dan penjabaran dari masing-masing poin di atas akan penulis paparkan di bawah ini.

\section{Al-Quran Menjaga Eksistensi dan Keajegan Bahasa Arab}

Sejarah bahasa-bahasa di dunia telah menjadi saksi, bahwa bahasa itu ada yang mampu bertahan hidup dan terus berkembang, tetapi ada juga bahasa yang mengalami kepunahan dan mati. Ada juga bahasa yang tetap hidup tetapi sudah mengalami perubahan yang signifikan, sehingga penutur bahasa yang sama sulit memahami bahasanya sendiri karena perbedaan waktu.

Bahasa-bahasa yang dulu pernah eksis dan sekarang sudah tidak lagi ada, di antaranya adalah Bahasa Phonician bahasa orang Libanon kuno, Bahasa Hieroglif bahasa orang Mesir kuno (periode $3200 \mathrm{SM}-400 \mathrm{M}$ ) ${ }^{18}$, Bahasa Sumeria yang pernah dituturkan di daerah yang sekarang disebut Irak, dan Bahasa Galia yang dituturkan di daerah yang sekarang disebut Perancis ${ }^{19}$.

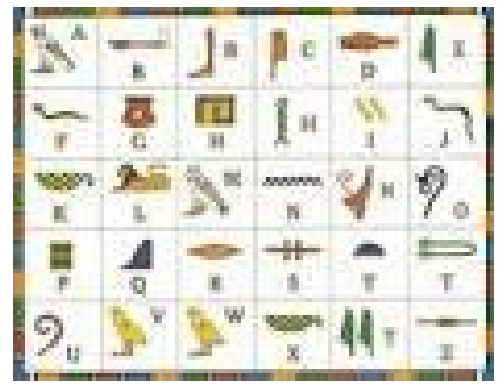

Ini adalah bentuk tulisan Hieroglif Mesir

\footnotetext{
${ }^{18}$ Muhammad Moehammed Dawud, al-'Arabiyah wa 'Ilm al-Lughah al-Hadithah, (Kairo: Dār Gharīb, 2001), 23

19 Wikipedia, "Bahasa-bahasa Mati", diambil dari http://id. wikipedia. org/ wiki/ Bahasa_mati diakses tanggal 18-05-2015.
} 
Sedangkan bahasa yang hidup tapi mengalami perubahan dari masa ke masa, sehingga penuturnya yang sekarang mendapatkan kesulitan untuk memahami bahasa yang sama yang dituturkan di masa lampau, di ataranya adalah Bahasa Inggris. Teks-teks Bahasa Inggris kuno yang berusia empat abad saja telah sulit difahami seperti karya-karya William Shakespeare (1564-1616 M), karya-karya tersebut harus ditulis ulang dalam versi Bahasa Inggris modern (Modern English) ${ }^{20}$. Apalagi Sastra Anglo-Saxon atau sastra Inggris kuno yang ditulis dalam Bahasa Inggris kuno (Old English) pada periode pasca Romawi dari kurang lebih pertengahan abad ke-5 sampai pada penaklukan Norman tahun $1066 \mathrm{M}^{21}$ tentu saja sudah mengalami banyak sekali perubahan.

Contoh lain dari perubahan yang terjadi dalam bahasa yang sama adalah Bahasa Indonesia. Bahasa ini lahir pada awal tahun 1920-an. Meskipun bahasa ini baru setengah abad berlangsung sampai sekarang (baca: 2015), namun dari segi ejaan sudah banyak mengalami perubahan. Perubahan ejaan dalam Bahasa Indonesia ini secara bertahap terjadi dalam beberapa model, yaitu ${ }^{22}$ :

1. Ejaan Van Ophuysen

Ejaan ini berlangsung sejak tahun dua puluhan dimana bahasa ini lahir sebagai warisan dari Bahasa Melayu.

2. Ejaan Soewandi (Ejaan Republik)

Ejaan yang menandakan berakhirnya Ejaan Van Ophuysen ini berlaku mulai 19 Maret 1947 sampai tahun 1972.

3. Ejaan Yang Disempurnakan (EYD)

Ejaan ini diterapkan secara resmi mulai tanggal 17 Agustus 1972 dengan SK Presiden RI nomor: 57/1972. Tetapi masih mengalami penyempurnaan pada tahun 1987 dan disempurnakan kembali pada tahun $2009 .^{23}$

Dengan demikian, ejaan Bahasa Indonesia yang ada saat ini akan sangat berbeda dengan ejaan Bahasa Indonesia pada beberapa tahun sebelumnya, khususnya pada periode Ejaan Republik dan Ejaan Ophuysen.

Lalu mari kita lihat perkembangan Bahasa Arab. Sebagaimana telah disinggung di atas, dalam kajian historis, dokumentasi Bahasa Arab yang

\footnotetext{
${ }^{20}$ Muhammed Moehammed Dawud, Op.Cit, 24.

${ }^{21}$ Wikipedia, "Sastra Inggris Kuno", dikutip dari laman http:// id.m. wikipedia. org/ wiki/ Sastra Inggris kuno pada tanggal 30 Mei 2015.

${ }^{22}$ Ibrahim Naki, Makalah "Ejaan yang disempurnakan" dikutip dari http:// www. Slideshare .net/mobile/ibrahimnaki/makalah-bahasa-indonesia-32608114, 3 diambil pada tanggal 31 Mei 2015.

23 Wikipedia, "Ejaan Yang Disempurnakan”, Dikutip dari http:// id.m. wikipedia .org/ wiki/Ejaan_Yang_Disempurnakan pada tanggal 31 mei 2015.
} 
paling lama ditemukan sekitar 150 tahun sebelum Islam $^{24}$, yaitu puisi Umru'ul Qayis ${ }^{25}$. Itu artinya teks tersebut sudah berumur 16 abad sampai sekarang (1436 H). Dan yang menakjubkan adalah keberadaan teks Bahasa Arab mulai dari 16 abad silam itu sampai sekarang tidak terdapat perubahan. Maksudnya semua orang dari masa ke masa dapat membaca teks tersebut dengan pembacaan dan pemaknaan yang sama. Tidak ada perubahan dari segi bacaan atau ejaan, tidak ada pula perubahan dari segi kosakata, dan tidak pula ada perubahan dari segi susunan bahasa (struktul gramatikalnya).

Pertanyaannya, faktor apa yang membuat seperti itu? Mari kita cari jawabannya, misalnya karena faktor bahasa Arabnnya sendiri sebagai bahasa Internasional. Faktanya bahwa bahasa internasional itu bukan hanya Bahasa Arab. Di samping itu ternyata Bahasa Arab sendiri baru resmi menjadi bahasa Internasional tertanggal 18 Desember 1973 dengan pengakuan PBB yang tertuang dalam resolusi nomor $3190 .{ }^{26}$ Itu artinya keinternasionalan Bahasa Arab ini tidak dapat menjadi faktor keistimewaan Bahasa Arab. Sebab Bahasa Arab sudah berkembang pesat jauh sebelum gelar internasional ala PBB itu ada.

Mungkin saja karena faktor bangsa Arab sebagai penutur bahasa ini, tetapi penutur bahasa Arab itu hanya sebagian kecil penduduk dunia, yaitu 22 negara yang menggunakan bahasa Arab secara resmi ${ }^{27}$, bandingkan dengan bahasa Inggris misalnya. Dari segi peradaban, bangsa Arab jauh terbelakang dibandingkan dengan peradaban Romawi dan Persia kala itu ${ }^{28}$. Dengan kata lain, bangsa Arab dan peradabannya -terutama sebelum Islam datang- tidak mungkin dapat menjadi faktor yang sangat berpengaruh terhadap perkembangan Bahasa Arab seperti sekarang.

Kalau begitu lalu faktor apa? Dari sekian faktor yang mungkin ada, hanya faktor al-Qur'an-lah yang paling mungkin dan rasional. Hal itu karena beberapa alasan:

1. Bahasa Arab menjadi pilihan Allah sebagai bahasa al-Qur'an.

Hal ini sudah jamak kita ketahui, kemudian dipertegas lagi oleh Allah Swt dalam ayat al-Qur'an yang berbunyi:

\footnotetext{
${ }^{24}$ Shauqi Dîif, Loc. Cit.

${ }^{25}$ Nama Aslinya adalah Abū al-Hārith Handaj bin Hajar al-Kindì, seorang penyair dari Yaman. Bapaknya adalah raja bagi Bani Asad di Najed.

${ }^{26}$ Muqaddimah Majmu'àt al-Buhūth (proceeding) "Al-Nadwah al-Dawliyah Hawla Tajribat al-Ta' 'imi al-Lughah al-'Arabiyah fi Indonesia”, UIN Maulana Malik Ibrahim Malang, tanggal 16-18 Desember 2011.

27 Pentingnya Bahasa Arab di Era Globalisasi, dikutip dari situs: www. https:// elfaiznamjha.wordpress.com/2013/09/17/pentingnya bahasa arab di era globalisasi/ diakses pada tanggal 11 Mei 2015.

${ }^{28}$ Muhammed Moehammed Dawud ${ }_{2}$ op.cit, 26
} 


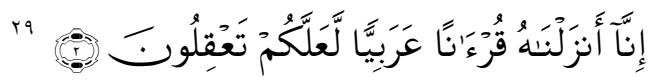

“Sesungguhnya Kami menurunkannya berupa al-Qur'an dengan berbahasa Arab, agar kamu memahaminya."

Pemilihan dari Allah ini tentu saja memiliki dampak positif yang luar biasa terhadap Bahasa Arab. Paling tidak karena poin kedua berikut ini:

2. Eksistensi Bahasa Arab mengikuti eksistensi al-Qur'an yang dijamin langsung oleh Allah Swt.

Nah, karena sudah menjadi bahasa al-Qur'an, maka apa yang terjadi pada al-Qur'an juga akan dialami oleh Bahasa Arab, salah satunya adalah jaminan eksistensi al-Qur'an yang dinyatakan oleh Allah dalam ayat berikut:

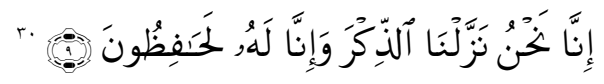

"Sesungguhnya Kami-lah yang menurunkan al-Qur'an, dan sesungguhnya Kami benar-benar memeliharanya ${ }^{31 " .}$.

Maka jaminan Allah terhadap eksistensi al-Qur'an ini menjadikan Bahasa Arab juga terjaga dari perubahan-perubahan, sehingga tetap stabil dan ajeg sampai sekarang bahkan sampai kelak di akhir zaman.

3. Al-Qur'an adalah wahyu Allah yang paling fasih, sehingga tidak terdapat perbedaan di dalamnya.

Alasan ketiga ini adalah alasan penguat yang membuktikan bahwa alQur'an itu benar-benar wahyu Allah Swt., dan kefasihan bahasanya menjadikan al-Qur'an itu tidak ada yang dapat menyangkal dari dulu sampai sekarang. Allah tegaskan dalam ayat berikut:

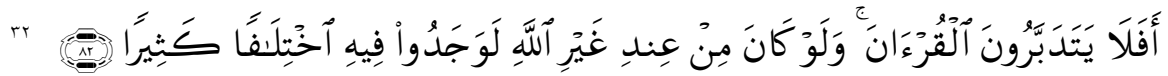

"Maka Apakah mereka tidak memperhatikan al-Quran? Kalau kiranya alQur'an itu bukan dari sisi Allah, tentulah mereka mendapat pertentangan yang banyak di dalamnya."

Disebutkan dalam kitab tafsir, bahwa yang dimaksud dengan ayat ini adalah dalam sisi fașāhah (kefasihan) bahasa al-Qur'an ${ }^{33}$. Dengan begitu, dalam aspek bahasanya al-Qur'an menjadi pedoman bahasa Arab dari masa ke masa, selain juga menjadi pedoman hidup umat manusia dari aspek substansi dan kandungan isi.

\footnotetext{
${ }^{29}$ QS. Yūusuf [12]: 2.

${ }^{30}$ QS. al-Hijr [15]: 9.

31 Ayat ini memberikan jaminan tentang kesucian dan kemurnian al-Qur' an selama-lamanya.

${ }^{32}$ QS. al-Nisā' [04]: 82.

33 Abū al-Qāsim Mahmūd bin 'Umar al-Zamakhsharī, al-Kashshāf, Vol. II, Cet. I, (Riyāụ: Maktab al-'Uwaikāt, 1998), 115.
} 


\section{Al-Qur'an Menambah Kosakata Bahasa Arab}

Salah satu bentuk kontribusi al-Qur'an yang konkret adalah adanya penambahan kosakata baru dalam Bahasa Arab yang belum dikenal sebelumnya. Beberapa kata baru yang belum dikenal sebelumnya itu antara lain: al-jāhiliyah (الجاهلية) yang berarti masa sebelum Islam datang ${ }^{34}$. Adapun ayat-ayat al-Quran yang memunculkan kata tersebut adalah:

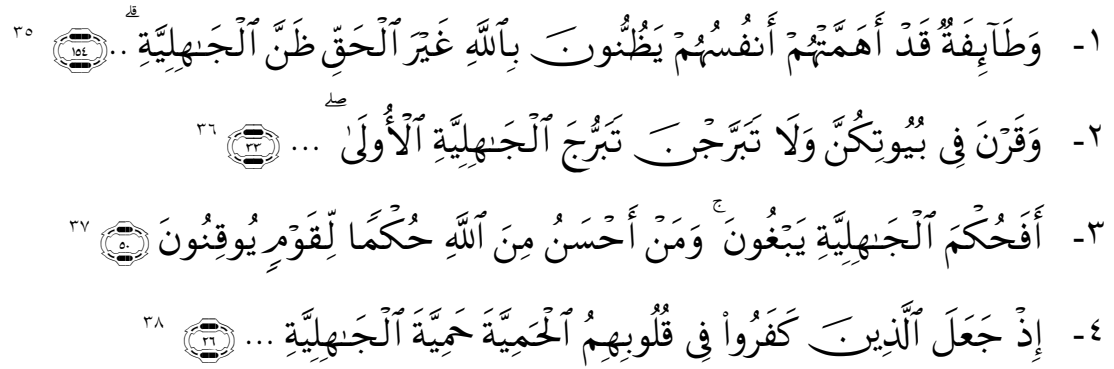

Ayat-ayat inilah yang pertama kali menggunakan istilah al-jāhiliyah dengan makna masa sebelum datangnya Islam.

Kata lain yang baru dimunculkan oleh al-Qur'an adalah al-munāfiq (المنافق). Kata al-munāfiq tidak dikenal sebelum Islam, lalu al-Qur'an menggunakan kata itu dengan maksud (dilālāt al-ma'nā) orang yang mengaku Islam hanya secara lisan tapi tidak diikuti dengan keyakinan hati ${ }^{39}$. Adapun ayat-ayat yang menyebutkan kata al-munāfiq (المنافق) dalam al-Qur'an dapat kita jumpai dalam banyak tempat di antaranya: (QS. al-Nisā' [04]: 61, 88, 138, 140, 142, dan 145 ), (QS. al-'Ankabūt [29]: 11), (QS. al-Fath [48]: 6), (QS. al-Munāfiqūn [63]: 1, 7, dan 8), (QS. al-Anfāl [08]: 49), (QS. al-Taubah [09]: 64, 67, 68, 73, dan 101), (QS. al-Ahzāb [33]: 12, 24, 48, 60, dan 83), (QS. al-Hadid [57]: 13) dan (QS. al-Tahrīim [66]: 9).

\section{Al-Qur'an Menambah Cakupan Makna Bahasa Arab}

Selain menambah kosakata baru dalam Bahasa Arab, al-Qur'an juga memperkaya bahasa Arab dengan menambah cakupan makna dari banyak sekali kosakata. Bahkan, ketika al-Qur'an menggunakan kata tersebut dengan makna barunya, maka kata-kata tersebut menjadi lebih popular daripada sebelumnya yang kurang terpakai.

\footnotetext{
${ }^{34}$ Zainal Abidin, Op.Cit, 57.

${ }^{35}$ QS. Âli Imrān [03]: 154.

${ }^{36}$ QS. al-Ahzāb [33]: 33.

${ }^{37}$ QS. al-Măidah [05]: 50.

${ }^{38}$ QS. al-Fath [48]: 26.

${ }^{39}$ Zainal Abidin, Loc. Cit.
} 
Adapun kata-kata yang sudah ada sebelum Islam tapi kemudian ditambahkan dengan makna baru oleh al-Qur'an, bahkan makna asal seakanالمؤمن- المسلم - الكافر - الصلاة - akan tidak kelihatan lagi tersebut antara lain adalah kata-kata ini memiliki cakupan makna yang berbeda dengan makna sebelum Islam datang. ${ }^{40}$

Kata الإيمان makna dasarnya adalah percaya terhadap apa saja secara mutlak. Tetapi kata iman yang pakai dalam al-Qur'an memberikan makna khusus, yaitu percaya kepada Allah Swt. dan kepada Malaikat Allah dan kepada kitab Allah dan kepada seluruh utusan Allah dan kepada hari akhir serta percaya kepada Taqdir Allah Swt. ${ }^{41}$

Kata الكافر bermakna "ketertutupan" secara mutlak. Sedangkan makna lain yang dipopulerkan oleh al-Qur'an adalah mendustakan apa yang dibawa Rasulullah Saw. meskipun sedikit. ${ }^{42}$

Kata الصلاة artinya adalah doa, tetapi al-Qur'an menggunakan kata ini dengan makna yang khas, yaitu perbuatan yang sudah tertentu dalam Islam dengan bacaan yang tertentu pula sebagaimana telah kita ketahui sampai sekarang. ${ }^{43}$

Kata الحج makna asalnya adalah berkehendak. Tetapi setelah al-Quran turun kata الحج digunakan dengan maksud berkehendak ke Baitullah al-Harām untuk melakukan ritual-ritual (manāsik) tertentu yang telah diajarkan dalam Islam dan perbuatan itu hanya pada bulan Zul Hijjah, maka sejak saat itu makna asalnya seakan telah terlupakan. ${ }^{44}$

\section{Al-Qur'an Menambah Gaya Bahasa (uslūb) Bahasa Arab}

Ketika al-Qur'an datang, pada saat yang sama Bahasa Arab mendapatkan tambahan gaya bahasa baru. Sebelumnya, gaya bahasa (uslüb) yang dikenal dalam bahasa Arab ada dua, yaitu uslüb syi'ir (puisi) dan uslüb nathar (prosa). Namun setelah al-Quran turun gaya bahasa Arab menjadi tiga: uslūb al-Qur'ān, uslüb al-shi'ri dan uslüb al-nathri ${ }^{45}$.

Syi'ir adalah gaya bahasa dalam ungkapan bahasa Arab yang khas ditandai dengan adanya wazan syi'ir dan diakhiri dengan huruf/bunyi huruf

\footnotetext{
${ }^{40}$ Ibid. 30

${ }^{41}$ Muhammed Moehammed Dawud ${ }_{2}$ op.cit, 36

42 Ibid.

${ }^{43}$ Ibid. 37

${ }^{44}$ Ibid.

${ }^{45}$ Ibid. 36
} 
yang sama atau serupa yang disebut dengan $q \bar{a} f i y a h .^{46}$ Sedangkan nathar merupakan ungkapan bahasa Arab yang bebas, artinya tidak terikat dengan harus adanya wazan dan qāfiyah seperti dalam syi'ir. ${ }^{47}$ Sementara al-Qur'an memiliki gaya bahasa yang khas tersendiri yang tidak dapat digolongkan dengan syi'ir, tetapi tidak bias juga dikatakan sebagai nathar.

\section{Al-Qur'an Menyatukan Lahjah Bahasa Arab}

Lahjah (dialek) bahasa Arab pada masa Jähiliyah (masa sebelum Islam datang) sangat banyak $^{48}$. Masing-masing kabilah memiliki lahjah yang berbeda dengan lainnya. Meskipun perbedaan itu tidak pada keseluruhan Bahasa Arab, tetapi ada perbedaan dalam pengucapan huruf tertentu, ada juga perbedaan dalam makna kata (dilālāt al-alfāa) dan ada juga perbedaan dari segi intonasi.

Adapun beberapa kabilah yang memiliki perbedaan lahjah saat itu, di antaranya: lahjah Tamim, lahjah Asad, lahjah Rabi'ah, lahjah Qais, lahjah Ṭayyi', lahjah Hudhail, lahjah Thaqiif, lahjah Maḍar, lahjah al-Azdi, lahjah Quḍ̄a' ah, lahjah Kilāb, lahjah Hamīr, lahjah Māzin, lahjah Qahțān dan lahjah lainnya ${ }^{49}$.

Meskipun perbedaan lahjah itu hanya sedikit dibandingkan dengan kesamaannya, tetapi tetap saja terasa sekali bedanya. Berikut penulis ringkaskan contoh-contoh lahjah yang berkembang pada masa Jāhiliyah sebagaimana ditulis oleh Shauqi Dif ${ }^{50}$ :

1. Lahjah Kashkashah (الكشكشة) atau Kaskasah (الكسكسة). Ada tiga kabilah yang disinyalir menggunakan lahjah ini, yaitu Banì Tamīm, Bani Asad dan Bani Rabì'ah. Lahjah ini menambahkan bunyi سي (ك) mukhạtab/mukhātabah. Seperti

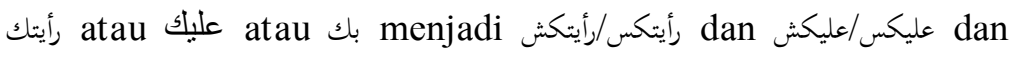
بكس/بكش.

2. Lahjah 'An'anah (العنعنة). Lahjah ini membunyikan huruf hamzah (ء) dengan 'Ain (ع). Contoh استدى (ع) dibunyikan dengan Lahjah ini dilakukan oleh Bani Tamīm, Banì Asad dan sebagian Bani Qais dan Tayyi’.

\footnotetext{
${ }^{46}$ Zainal Abidin, Op.Cit, 2

${ }^{47}$ Ibid. 1.

${ }^{48}$ Shauqi Dịf, Op.cit, 121.

${ }^{49}$ Ibid.

${ }^{50}$ Ibid, 121-124.
} 
3. Lahjah Fahfahah (الفحفحة). Ini terdapat pada Bani Hudhail, dan sebagian Bani Thaqif dan Bani Maḍar. Lahjah ini mengganti bunyi huruf 'ain $(\varepsilon)$ dengan bunyi huruf ha' $(\tau)$.

4. Lahjah al-Istinta' (الاستنطاء). Lahjah ini terkenal di Bani Mudar dan Banī Qahțān, yaitu mengganti bunyi 'ain ( $)$ (engan bunyi huruf nūn (ن). أعطى Seperti dibaca dengan أنطى.

5. Lahjah al-Tiltilah (الثلتلة). Lahjah ini digunakan oleh Bani Qựāah dan Bañi Bahrā' dari Banì Qahțān. Lahjah ini saat ini juga dipakai oleh orang-orang Mesir, yaitu mengkasrahkan $(\rightarrow)$

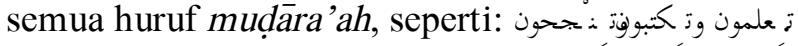

6. Lahjah al-Wihim ( $(r$ ). Lahjah ini mengkasrahkan $(\rightarrow)$ semua damir ha' (هم/ه) meskipun sebelumnya bukan ya' atau bukan kasrah, seperti: منهموعنه Lahjah ini dipopulerkan oleh Bani Kilāb.

7. Lahjah al-Wikim (وك). Hampir sama dengan lahjah al-wihim, yaitu dengan mengkasrahkan $(\rightarrow)$ huruf Kaf (s) damir mukhātab/mukhāțabah. Contoh: عليك

8. Lahjah al-Tamtamaniyah (الطمطمانية). Lahjah ini sekarang juga popular di Mesir, yaitu mengganti bunyi huruf lam (J) dengan bunyi huruf mim (م). Contoh: امسهم وامبر menjadi السهم والبر والصيام (U) وامصيام. Dulu lahjah ini digunakan oleh orang Yaman dan Bani Hamīr serta sebagian Bani Ṭayyi’.

9. Lahjah al-Shinshinah (الشنشنة). Lahjah ini juga dipopulerkan oleh orang Yaman, yaitu dengan menggantikan bunyi huruf kaf (s) damir dengan bunyi huruf Shin (ش), seperti: بيك اللهم لبيك menjadi

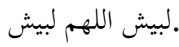

10. Ada juga lahjah Bani Hamir yang menggantikan bunyi huruf sin (س) dengan bunyi huruf ta' (ت), sehingga kata الناس mereka bunyikan dengan النات;

11. Dan masih ada beberapa perbedaan lahjah lain pada beberapa kabilah di masa Jahiliyah.

Dari beberapa lahjah yang terdapat pada masa Jahiliyah tersebut terdapat satu lahjah yang dominan yaitu lahjah Quraish. Dialek yang 
digunakan oleh mayoritas penduduk Makkah ini dipakai oleh para sastrawan kala itu sebagai bahasa Sastra Arab.

Lalu al-Qur'an datang dengan bahasa Arab yang menyatukan semua lahjah. Tentu saja al-Qur'an tetap menggunakan lahjah Quraisy yang sudah disepakati sebagai bahasa sastra sebelumnya, lebih dari itu al-Qur'an juga mengadopsi beberapa lahjah terbaik dari beberapa lahjah kabilah bangsa Arab lainnya. Sehingga bahasa yang dipakai al-Qur'an kemudian benarbenar menjadi bahasa Arab al-mushtarakah.

\section{Al-Qu'an Memperluas Ketersebaran Bahasa Arab}

Bahasa Arab terus tersebar luar ke daerah-daerah di luar negaranegara Arab bersamaan dengan al-Qur'an, seperti di Mesir, Syria, Persia, Romawi, Afrika Utara, bahkan ke Melayu ${ }^{51}$.

Semenjak al-Qur'an turun dan manusia mulai berbondong-bondong memeluk agama Islam dari seluruh belahan dunia, pada saat yang sama mereka juga mempelajari Bahasa Arab agar dapat mengetahui lebih dalam tentang tata cara membaca al-Qur'an, memahami al-Qur'an, melaksanakan ibadah, dan memahami ajaran-ajaran agama Islam. Terlebih lagi, membaca al-Qur'an mempunyai keistimewaan karena hanya dengan membaca saja seseorang akan mendapatkan pahala, sebab hal itu bagian dari ibadah kepada Allah Swt. (al-ta'abbud ilā Allāh). Oleh karena itu, tersebarnya Bahasa Arab sehingga meluas ke pelbagai penjuru dunia tidak lain karena faktor alQur'an ${ }^{52}$.

\section{Al-Qur'an Memperkaya Sastra Bahasa Arab}

Kehadiran al-Qur'an tidak hanya mewarnai kehidupan umat dari aspek doktrinnya saja. Al-Qur'an hadir juga turun andil dalam memperkaya sastra Arab dan nilai-nilai estetika di dalamnya. Berikut beberapa poin yang sangat konkret menjadi kontribusi al-Qur'an di bidang sastra:

1. Memperhalus sastra Arab: dengan adanya uslüb al-Qur'an taste (dhauq) sastra Arab memasuki babak baru, yaitu dari sastra yang beraroma keras, terbelakang dan kuno menjadi sastra Arab yang berperadaban tinggi ${ }^{53}$.

Hal itu dapat terlihat dari tema-tema sastra yang berkembang di masa Jahiliyah, kebanyakan hanya seputar fanatisme kelompok (kabilah), ratapan, dan cemoohan. Meskipun ada tema-tema yang

\footnotetext{
${ }^{51}$ Zainal Abidin, Op.cit, 57.

${ }^{52}$ Muhammed Moehammed Dawud ${ }_{2}$ op.cit, 39

${ }^{53}$ Zainal Abidin, Op.cit, 58
} 
lebih maju seperti zuhud, pujian, dan percintaan tetapi nuansa sastra dari tema-tema tersebut masih sangat kuno.

Namun al-Qur'an memberikan nuansa baru dalam tema-tema sastra. Al-Qur'an memberikan sentuhan-sentuhan peradaban yang tinggi dalam sastra Arab, semisal pembangunan manusia dengan akhlak alkarimah, pembangunan ekonomi syariah, pembentukan keluarga sakinah sebagai pilar pembangunan kebangsaan yang maju dan sejahtera serta tema-tema lain yang sarat dengan peradaban manusia yang ideal.

2. Al-Qur'an semakin menaikkan nilai estetika ungkapan-ungkapan sastra Arab. Hal ini karena para sastrawan dan pera orator banyak yang menggunakan gaya bahasa al-Qur' an atau mengutip bahasa alQur'an dalam karya sastra mereka ${ }^{54}$.

3. Banyaknya cerita dalam al-Qur'an mendorong umat Islam untuk mempelajari sejarah bangsa-bangsa terdahulu ${ }^{55}$.

4. Al-Qur'an berhasil menghidupkan jenis sastra baru, seperti cerita, sastra zuhud dan sastra sejarah yang belum banyak dikenal sebelumnya kemudian sangat berkembang sampai sekarang. AlQur'an juga mematikan jenis sastra yang tidak bermoral, seperti cemoohan (hija'), fanatisme kesukuan dan perdukunan. ${ }^{56}$

\section{Al-Qur'an Menjadi Sumber Munculnya Ilmu-ilmu Bahasa Arab}

Al-Qur'an sebagai pedoman hidup bagi yang bertaqwa (هدى للمتقين) sudah barang tentu menjadi rujukan utama umat Islam di seluruh penjuru dunia. Namun demikian, tidak semua orang dapat memahami al-Qur'an dengan baik. Karena untuk dapat menangkap makna yang terkandung di dalam al-Qur'an diperlukan seperangkat ilmu yang bersentuhan langsung dengan Bahasa Arab sebagai bahasa pengantar al-Kitāb ini. Di samping itu, juga dibutuhkan ilmu-ilmu tentang hal-hal yang terkait langsung dengan konteks ayat perayat di dalamnya, seperti asbāb al-nuzūl, nāsikh dan mansūkh, muțlak dan muqayyad, makkỉ dan madañi, dan lain-lain.

Oleh karena itu, para ulama Islam dan kaum akademisi dari dulu sampai sekarang berusaha untuk mendekatkan al-Qur'an kepada umat Islam secara keseluruhan dengan cara merumuskan ilmu-ilmu sebagai alat untuk memahami kitab suci tersebut. Di antara ilmu-ilmu yang berhubungan dengan Bahasa Arab sebagai bahasa al-Qur'an adalah:

\footnotetext{
54 Ibid.

55 Ibid.

${ }^{56}$ Ibid.
} 
1. Ilmu Nahwu: yaitu kaidah tata bahasa Arab yang bersentuhan dengan struktur bahasa dan sintaksisnya (al-i'rāb). ${ }^{57}$

2. Ilmu Șarf: merupakan ilmu yang berhubungan dengan morfem (bentuk) kata dalam Bahasa Arab. ${ }^{58}$

3. Ilmu Balaghah: ilmu ini dibagi menjadi tiga bagian yang semuanya berhubungan dengan Bahasa Arab; yaitu ilmu alma'āni yang membahas tentang hubungan kalimat (ungkapan) bahasa Arab dengan konteks kalam dalam segi makna; ilmu albayān yang membahas tentang jenis-jenis kalimat (ungkapan) bahasa Arab dalam aspek penggunaan al-tashbìh, al-majāz dan al-kināyah; ilmu al-badi' merupakan ilmu yang khusus mengakaji aksesoris bahasa Arab sehingga menambah tinggi nilai keindahannya atau bahkan dapat menguranginya karena kesalahan dalam penggunaannya, misalnya tentang al-jinās, almuqābalah, al-iltifät, al-tawriyah dan lain-lain. ${ }^{59}$

Sementara ilmu-ilmu yang berhubungan dengan substansi al-Qur'an secara langsung tentang ayat perayat antara lain:

1. Ulumul Qur'an: ilmu yang membahas tentang semua hal yang berhubungan dengan al-Qur'an dan untuk melayani al-Qur'an ${ }^{60}$;

2. Tafsir dan Ilmu Tafsir: ilmu untuk mengetahui pemahaman tentang al-Qur'an dan penjelasan maknanya serta istinbāt hukum di dalamnya $^{61}$;

3. Manāhij al-Mufassirīn: ilmu yang khusus membahas macam-macam metode penafsiran para ulama mufassir,

4. Dan lain-lain.

Sedangkan dalam ilmu-ilmu bahasa Modern yang juga masih terkait dengan al-Qur'an adalah:

1. Semantik (Ilmu al-Dilālah): adalah cabang linguistik yang mempelajari arti atau makna yang terkandung pada suatu bahasa, kode, atau jenis representasi lain. Dengan kata lain, Semantik adalah pembelajaran tentang makna ${ }^{62}$.

\footnotetext{
57 Al-Sayyid Ahmad al-Hashimī, Jawāhir al-Balāghah, (Bairut: Al-Maktabah Al-‘Așriyah, 1999), 16

58 Ibid.

${ }^{59}$ Ibid.

${ }^{60}$ Muhammad Abdul 'Aẓìm al-Zarqānī, Manāhil al- 'Irfān fí 'Ulūm al-Qur'ān, (Bairut: Dār alKitāb al-Arabì, 1995), 23.

${ }^{61}$ Badr al-Din Muhammad bin Abdillah al-Zarkashì, al-Burhān fí 'Ulūm al-Qur'ān, (Kairo: Maktabah Dār al-Turāth, tt), 13

${ }^{62}$ Wikipedia, https://id.wikipedia.org/wiki/Semantik diakses tanggal 29 Juni 2015.
} 
2. Hermeunitika: adalah salah satu jenis filsafat yang mempe-lajari tentang interpretasi makna ${ }^{63}$.

3. Dan lain-lain.

\section{Epilog}

Dari penjabaran singkat di atas, penulis dapat simpulkan bahwa kontribusi al-Qur'an terhadap perkembangan Bahasa Arab sangat jelas, konkret dan nyata. Dari data-data yang ada tidak ada lagi keraguan bahwa keistimewaan Bahasa Arab yang sekarang ada dan kemunculan ilmu-ilmu pengetahuan erat sekali hubungannya dengan al-Qur'an.

Kontribusi al-Qur'an ada yang bersifat materiil seperti dalam penambahan kosakata baru atau memperluas cakupan maknanya dan penambahan uslüb baru dalam Bahasa Arab. Selain itu ada kontribusi yang bersifat in-material yang abstrak tetapi terasa sangat jelas. Hal itu dapat kita lihat dalam menjaga eksistensi dan keajegan Bahasa Arab bahkan sampai pada masa-masa yang akan datang.

Dengan demikian, kontribusi Al-Qur'an terhadap Bahasa Arab dan perkembangannya dapat kita golongkan ke dalam dua katagori; konkret dan abstrak. Kendati demikian keterkaitan keduanya sangatlah terang benderang, seperti matahari di siang hari di atas langit yang jernih tanpa awan. Wallāhu a'lam.

\section{Daftar Pustaka}

Al-Bughbisy, Abdul Karim. "Daur al-Qur'ān fî Tațawwur al-Lughah al"Arabiyah wa Adābihā" dalam http://www. Diwanalarab .com/ spip.php?page $=$ article\&id article $=25795$ diakses tanggal 18 Mei 2015.

Al-Būrini, Abdu al-Rahmān 'Ahmad. al-Lughah al-'Arabiyah Aṣl al-Lughāt Kulliḥā. Oman: Dār al-Hasan, 1998.

Al-Dad, Sayyid Ibrāhīm Muhammad. Muhadarāt fì Tārīkh al-Adab al-'Arabì 'Așr Sadr al-Islām. Kairo: Jāmi'àt al-Azhar, 2004.

Dawud, Muhammed Moehammed. Al-'Arabiyah wa 'Ilm al-Lughah alHadithah. Kairo: Dār Gharib, 2001.

Dịif, Shauqi. Tärikh al-Adab al-'Arabī al-'Aṣr al-Jāhili. Cet. Ke-24. Kairo: Dār al-Ma'ārif, tt.

Al-Hashimī, al-Sayyid Ahmad. Jawāhir al-Balāghah. Bairut: Al-Maktabah al-'Așriyah, 1999.

\footnotetext{
${ }^{63}$ Wikipedia, https://id.wikipedia.org/wiki/Hermeneutika diakses tanggal 29 Juni 2015.
} 
http://id.m.wikipedia.org/wiki/Ejaan_Yang_Disempurnakan pada tanggal 31 mei 2015.

Majmu'āt al-Buhūth (proceeding). "Al-Nadwah al-Dawliyah hawla Tajribat Ta'Timi al-Lughah al-“Arabiyah fí Indonesia”. UIN Maulana Malik Ibrahim Malang, tanggal 16-18 Desember 2011.

Naki, Ibrahim. Makalah "Ejaan yang disempurnakan" dikutip dari http://www.slideshare.net/mobile/ibrahimnaki/makalah-bahasaindonesia-32608114, diambil pada tanggal 31 mei 2015.

Al-Qādir, Zainal 'Abidin Haji Abd. Mudhakkirah fí Tārikh al-Adab alArabì. Kuala Lumpur: Kementerian Pendidikan Malaysia, 1987.

Salāmah, Khaldūn Ibrāhim. al-Thaqāfah al-Islāmiyah al-Mustawā al-Thālith. Riyāụ: Jāmi'ah al-Imām Muhammad bin Saūd al-Islāmiyah, tt.

www.https://elfaiznamjha.wordpress.com/2013/09/17/pentingnya_bahasa_ar ab_di_era_globalisasi/, diakses pada tanggal 11 Mei 2015 .

Al-Zamakhsharī, Abū al-Qāsim Mahmūd bin 'Umar. Al-Kashshāf, Juz II, Cet. I. Riyāḍ: Maktab al-'Uwaikāt, 1998.

Al-Zarkashī, Badrud al-Dìn Muhammad bin Abdillah. Al-Burhān fí 'Ulüm al-Qur'ān. Kairo: Maktabah Dār al-Turāth, tt.

Al-Zarqānī, Muhammad Abdul Aẓim. Manāhil al-'Irfān fì 'Ulūm al-Qur'ān. Bairut: Dār al-Kitāb al-Arabi, 1995.

Zidane, Joergi. al-Lughah al-'Arabiyah Kāinun Hayyun. Beirut: Dār al-Jail, cet. Ke-8, 1988. 